\title{
The use of phytase in broiler chicken diets containing maize and soyabean or rapeseed meal
}

\author{
A. Rutkowski, B. Śliwiński and Maria Wiąz \\ Department of Animal Nutrition and Feed Management, \\ Poznań Agricultural University \\ Wolyńska 33, 60-637 Poznań, Poland
}

(Received 3 July 1997; accepted 24 October 1997)

\begin{abstract}
Two experiments were carried out to ascertain the possibilities of reducing the use of fodder phosphates in maize-soyabean meal and maize-rapeseed meal based diets for broiler chickens with the aid of phytase. In experiment 1, performed on 560 broilers (equal numbers of males and females), the effect of phytase on growth rate, feed consumption and feed conversion ratio was evaluated. The use of phytase resulted in improvement of feed consumption and body weight gains of chickens, but had no effect on feed conversion ratio. Phytase supplementation improved dressing percentage, especially in maize-rapeseed groups. In the balance experiment, performed on 80 chicks, $\mathrm{Ca}$ and $\mathrm{P}$ availability was determined. The use of phytase increased phosphorus availability by $24 \%$ in the case of soyabean diets, and by up to $29 \%$ in the case of rapeseed meal diets. The use of phytase allows production of broiler chickens using diets in which the total phosphorus level can be reduced by $33 \%$.
\end{abstract}

KEY WORDS: phytase, phosphorus digestibility, rapeseed meal, broiler chickens

\section{INTRODUCTION}

In feeds of plant origin, only $1 / 3$ of the phosphorus is available to birds, the remaining $2 / 3$ occurs in the form of phytic acid and phytates, and remains unavailable to chickens. This is due to the lack of endogenous phytase in the gastrointestinal tract of chicks. Moreover, phytic acid and phytates also reduce availability of other minerals and proteins (Kratzer and Vohra, 1986). 
In recent years growing interest has been observed in microbial phytase manufactured specially for use in feeds, obtained from various fungi, e.g. Aspergillus ficuum. Nelson et al. (1971) showed that this enzyme can improve the utilization of phytic phosphorus by chickens. In recent years studies on application of phytase in poultry feeding have been conducted by, among others, Żyla and Koreleski (1993), Jeroch (1994), Dänicke et al. (1995), Potkański et al. (1995), Rutkowski and Potkański (1995). The use of phytase in diets improves digestibility of total dietary phosphorus, reduces costs of diets due to the decrease of fodder phosphates, has a positive influence on the natural environment as the result of reducing phosphorus emissions in faeces, and improves absorption of some trace elements (e.g. $\mathrm{Zn}, \mathrm{I}$ ).

Rapeseed meal (RSM) is characterized by an exceptionally high concentration of total phosphorus. There may be up to $11.2 \mathrm{~g}$ of total phosphorus in $1 \mathrm{~kg}$ of RSM (Nutrient Requirements of Poultry, 1996) but the level of its availability is low and does not usually exceed 25\% (Nwokolo and Bragg, 1980). It appears that if its availability could be improved, rapeseed meal could become a relatively cheap source of phosphorus for broiler chickens.

The objective of this research project was to assess the possibilities of restricting the use of fodder phosphates in diets for broiler chickens by the inclusion of phytase in diets based on maize, soyabean meal and rapeseed meal.

\section{MATERIAL AND METHODS}

Two experiments were carried out on 640 one-day old Avian 43 broiler chicks of average initial body weight of $45.4 \mathrm{~g}$, which were purchased from a commercial hatchery. In order to ensure equal share of both sexes, the birds were sexed using the Japanese method. The object of studies was NOVO CLTM phytase with an activity of $2500 \mathrm{FYT} / \mathrm{g}$. The enzyme was added to maize-soyabean and maize-rapeseed diets. The composition of the diets is shown in Tables 1 and 2 . In both experiments, the following eight diets were used: 1 (control) - a maize-soyabean meal diet containing $0.77 \%$ total phosphorus (Pt); in diets 2,3 and 4 the level of $\mathrm{Pt}$ was lowered to $0.58 \%$, diet 2 was unsupplemented, 3 supplemented with 250 and diet 4 with 750 units of phytase per $\mathrm{kg}$; 5 (control) was a maize-rapeseed meal diet containing $0.84 \mathrm{Pt}$, in diets 6, 7 and 8 the Pt level was lowered to $0.65 \%$, diet 6 was fed unsupplemented, 7 supplemented with 250 and diet 8 with 750 units of phytase per $\mathrm{kg}$.

Experiment 1 was conducted on 560 chickens divided into eight groups, each group consisted of 70 birds. The birds were kept in cages of 10 chickens treated as replicates. They were fed ad libitum complete starter dry rations (Table 1) for the first three weeks and grower rations from week four to six (Table 2). The 
TABLE 1

Composition of experimental diets used in Starter period, \%

\begin{tabular}{|c|c|c|c|c|c|c|c|c|}
\hline \multirow{2}{*}{ Item } & \multicolumn{8}{|c|}{ Group } \\
\hline & 1 & 2 & 3 & 4 & 5 & 6 & 7 & 8 \\
\hline Maize & 51.0 & 51.7 & 51.69 & 51.67 & 45.9 & 46.5 & 46.49 & 46.47 \\
\hline Soyabean meal $(43 \%)$ & 36.4 & 36.2 & 36.2 & 36.2 & 25.2 & 25.2 & 25.2 & 25.2 \\
\hline Rapeseed meal OO & - & - & - & - & 15.0 & 15.0 & 15.0 & 15.0 \\
\hline Meat meal $(55 \%)$ & 5.0 & 5.0 & 5.0 & 5.0 & 5.0 & 5.0 & 5.0 & 5.0 \\
\hline Rape seed oil & 5.0 & 5.0 & 5.0 & 5.0 & 6.5 & 6.5 & 6.5 & 6.5 \\
\hline Dicalcium phosphate & 1.2 & 0.2 & 0.2 & 0.2 & 1.1 & 0.1 & 0.1 & 0.1 \\
\hline Limestone & - & 0.5 & 0.5 & 0.5 & - & 0.5 & 0.5 & 0.5 \\
\hline Starter premix* & 1.2 & 1.2 & 1.2 & 1.2 & 1.2 & 1.2 & 1.2 & 1.2 \\
\hline Phytase & - & - & 0.01 & 0.03 & - & - & 0.01 & 0.03 \\
\hline \multicolumn{9}{|l|}{ Calculated: } \\
\hline crude protein, $\%$ & 23.0 & 23.0 & 23.0 & 23.0 & 23.0 & 23.0 & 23.0 & 23.0 \\
\hline $\mathrm{ME}_{\mathrm{N}}, \mathrm{MJ} / \mathrm{kg}$ & 12.8 & 12.8 & 12.8 & 12.8 & 12.8 & 12.8 & 12.8 & 12.8 \\
\hline $\mathrm{Ca}, \%$ & 0.98 & 0.97 & 0.97 & 0.97 & 1.02 & 1.00 & 1.00 & 1.00 \\
\hline total $\mathrm{P}, \%$ & 0.77 & 0.58 & 0.58 & 0.58 & 0.84 & 0.65 & 0.65 & 0.65 \\
\hline available $\mathrm{P}, \%$ & 0.46 & 0.31 & 0.31 & 0.31 & 0.46 & 0.31 & 0.31 & 0.31 \\
\hline
\end{tabular}

* vitamin - mineral premix $1.0 ; \mathrm{NaCl} 0.2 \%$

TABLE 2

Composition of experimental diets used in the Grower period, \%

\begin{tabular}{lcccccccc}
\hline & \multicolumn{1}{c}{ Group } \\
\cline { 2 - 9 } Item & 1 & 2 & 3 & 4 & 5 & 6 & 7 & 8 \\
\hline Maize & 61.3 & 61.7 & 61.59 & 61.57 & 52.7 & 53.2 & 53.19 & 53.17 \\
Soyabean meal $(43 \%)$ & 28.5 & 28.4 & 28.5 & 28.5 & 10.1 & 10.0 & 10.0 & 10.0 \\
Rapeseed meal OO & - & - & - & - & 25.0 & 25.0 & 25.0 & 25.0 \\
Meat meal (55\%) & 4.0 & 4.0 & 4.0 & 4.0 & 4.0 & 4.0 & 4.0 & 4.0 \\
Rape seed oil & 4.0 & 4.0 & 4.0 & 4.0 & 6.0 & 6.0 & 6.0 & 6.0 \\
Dicalcium phosphate & 1.0 & 0.2 & 0.2 & 0.2 & 1.0 & 0.1 & 0.1 & 0.1 \\
Limestone & - & 0.5 & 0.5 & 0.5 & - & 0.5 & 0.5 & 0.5 \\
Grower premix & 1.2 & 1.2 & 1.2 & 1.2 & 1.2 & 1.2 & 1.2 & 1.2 \\
Phytase & - & - & 0.01 & 0.03 & - & - & 0.01 & 0.03 \\
Calculated: & & & & & & & & \\
$\quad$ crude protein in \% & 20.0 & 20.0 & 20.0 & 20.0 & 20.0 & 20.0 & 20.0 & 20.0 \\
ME, $\mathrm{MJ} / \mathrm{kg}$ & 13.0 & 13.0 & 13.0 & 13.0 & 12.8 & 12.8 & 12.8 & 12.8 \\
Ca, \% & 0.87 & 0.87 & 0.87 & 0.87 & 0.94 & 0.94 & 0.94 & 0.94 \\
total P, \% & 0.69 & 0.54 & 0.53 & 0.53 & 0.83 & 0.66 & 0.66 & 0.66 \\
$\quad$ available P, \% & 0.39 & 0.27 & 0.26 & 0.26 & 0.39 & 0.25 & 0.25 & 0.25 \\
\hline
\end{tabular}

* vitamin - mineral premix $1.0 ; \mathrm{NaCl} 0.2 \%$ 
following evaluation criteria were adopted: body weight gain (BWG) and feed consumption was measured once a week in each replicate, and feed conversion ratio (FCR) calculated. At the termination of the experiment, 6 chickens (three hens and 3 cockerels) were randomly selected from each group, slaughtered by decapitation, wet plucked, eviscerated and chilled. Dressing percentage of carcasses was calculated in relation to weight of birds before slaughter. Dissection analysis was performed as follows: after cutting off the neck, the carcass was halved along the back and crest, the right half was weighed and abdominal fat, skin with subcutaneous fat, breast and leg muscles and remaining parts were separated as described by Baryłko-Pikielna (1975).

The 2 second - balance experiment - was carried out on three-week old cockerels fed the same starter diet. During the trial, birds were kept in individual balance cages. In each of the eight feeding groups there were 10 cockerels treated individually. During the experiment birds received the same starter diets ad libitum as in Experiment 1 (Table 1). After a three day initial feeding period (adaptation of the birds to experimental conditions) feed consumption was measured and excreta were collected quantitatively for the following three days. The collected excreta were weighed, stored in a freezer (at $-18^{\circ} \mathrm{C}$ ), then freeze-dried and subjected to chemical analyses. The $\mathrm{P}$ content in diets and excreta was measured by the molybdovanadate method, the content of $\mathrm{Ca}$ by flame photometry according to Olsen and Sommers (1982). Utilization coefficients of calcium and phosphorus were calculated.

All results were subjected to statistical analysis with the aid of the Statgrafic ver. 6 computer program.

\section{RESULTS AND DISCUSSION}

In control diets ( 1 and 5) the content of available phosphorus agreed with that recommended for broiler chickens (Nutrient Requirement of Poultry, 1996). In low phosphorus diets 2,3 and 4 , and 6,7 and 8 the quantity of available phosphorus ( $\mathrm{Pa}$ ) was reduced by $33 \%$ (Tables 1 and 2 ). It resulted in a reduction of body weight gains (BWG) (Table 3 ) in groups 2 and 6 by 8 and $4 \%$ in relation to the respective control groups ( 1 and 5 ). Phytase supplementation, similarly as in studies by Jeroch (1994), in all cases resulted in improvement of BWG in relation to unsupplemented groups ( 2 and 6 ). In the case of maize-soyabean diets, 250 units of phytase per $\mathrm{kg}$ proved sufficient and increasing its level to 750 units per kg did not further improve BWG. In both groups BWG was $3 \%$ lower than recorded in the control group (1), but in contrast to the unsupplemented group (2), these differences were statistically non-significant. 
TABLE 3

Body weight gain of chickens, feed intake and feed conversion ratio

\begin{tabular}{|c|c|c|c|c|c|c|c|c|c|}
\hline \multirow{2}{*}{$\begin{array}{l}\text { Week } \\
\text { of life }\end{array}$} & \multicolumn{8}{|c|}{ Group no } & \multirow{2}{*}{ SEM } \\
\hline & 1 & 2 & 3 & 4 & 5 & 6 & 7 & 8 & \\
\hline \multicolumn{10}{|c|}{ Body weight gain, $g$} \\
\hline $0-3$ & $0.506^{\mathrm{cd}}$ & $0.465^{\mathrm{h}}$ & $0.497^{\mathrm{cd}}$ & $0.492^{\text {cd }}$ & $0.483^{\mathrm{bc}}$ & $0.436^{\mathrm{a}}$ & $0.486^{\mathrm{bcd}}$ & $0.507^{\mathrm{d}}$ & 0.008 \\
\hline $4-6$ & $1.133^{\mathrm{e}}$ & $1.049^{\mathrm{cd}}$ & $1.096^{\mathrm{de}}$ & $1.104^{\mathrm{de}}$ & $0.963^{\mathrm{ab}}$ & $0.951^{\mathrm{a}}$ & $0.964^{\mathrm{ab}}$ & $1.020^{\mathrm{bc}}$ & 0.024 \\
\hline $0-6$ & $1.639^{\mathrm{e}}$ & $1.514^{\mathrm{tx}}$ & $1.593^{\mathrm{de}}$ & $1.596^{\mathrm{de}}$ & $1.446^{\mathrm{ab}}$ & $1.387^{\mathrm{a}}$ & $1.450^{\mathrm{ab}}$ & $1.527^{\mathrm{cd}}$ & 0.026 \\
\hline$\% *$ & 100 & 92 & 97 & 97 & 100 & 96 & 100 & 106 & \\
\hline \multicolumn{10}{|c|}{ Feed consumption, $\mathrm{g}$} \\
\hline $0-3$ & $817^{b}$ & $791^{\mathrm{ab}}$ & $792^{\mathrm{b}}$ & $786^{\mathrm{ab}}$ & $810^{\mathrm{b}}$ & $751^{\mathrm{a}}$ & $821^{\mathrm{b}}$ & $801^{\mathrm{b}}$ & 14 \\
\hline $4-6$ & $2271^{\mathrm{cd}}$ & $2173^{\mathrm{ab}}$ & $2234^{\text {bcd }}$ & $2231^{b \mathrm{bcd}}$ & $2203^{\mathrm{ab}}$ & $2126^{\mathrm{a}}$ & $2201^{\mathrm{ab}}$ & $2316^{d}$ & 33 \\
\hline $0-6$ & $3088^{c}$ & $2964^{\mathrm{ab}}$ & $3026^{\mathrm{bc}}$ & $3017^{\mathrm{bc}}$ & $3013^{b c}$ & $2877^{a}$ & $3022^{b c}$ & $3117^{c}$ & 41 \\
\hline$\% *$ & 100 & 96 & 98 & 98 & 100 & 95 & 100 & 103 & \\
\hline \multicolumn{10}{|c|}{ Feed conversion ratio, $\mathrm{g}$ feed/g BWG } \\
\hline $0-3$ & $1.61^{\mathrm{ab}}$ & $1.70^{\mathrm{d}}$ & $1.59^{\mathrm{ab}}$ & $1.60^{\mathrm{ab}}$ & $1.68^{\mathrm{bcd}}$ & $1.73^{\mathrm{d}}$ & $1.69^{\text {at }}$ & $1.58^{\mathrm{a}}$ & 0.031 \\
\hline $4-6$ & $2.01^{a}$ & $2.07^{\mathrm{a}}$ & $2.04^{a}$ & $2.03^{\mathrm{a}}$ & $2.29^{\mathrm{b}}$ & $2.24^{\mathrm{b}}$ & $2.29^{\mathrm{b}}$ & $2.27^{b}$ & 0.046 \\
\hline $0-6$ & $1.88^{\mathrm{a}}$ & $1.95^{\mathrm{ab}}$ & $1.89^{\mathrm{a}}$ & $1.88^{\mathrm{a}}$ & $2.08^{c}$ & $2.07^{\mathrm{c}}$ & $2.08^{c}$ & $2.04^{\mathrm{bc}}$ & 0.032 \\
\hline$\% *$ & 100 & 104 & 100 & 100 & 100 & 99 & 100 & 98 & \\
\hline
\end{tabular}

* percentange of indices of relative control groups ( 1 for SBM, 5 for RSM diets)

a, $b-$ means in rows designated by different superscripts differ significantly at $P \leqslant 0.05$

A more visible influence of phytase was observed in maize-rapeseed diets which were richer in Pt than maize-soyabean-based diets. Chickens fed diets with the lower level of phytase reached the same weight at the termination of the experiment as those from the control group, while the birds which were given diets with 750 units of phytase per $\mathrm{kg}$ were $6 \%$ heavier than the birds from the control group. This difference was statistically significant at $\mathbf{P} \leqslant 0.05$.

In maize-soyabean diets supplemented with phytase, the feed conversion ratio (FCR) (Table 3) decreased by $2 \%$ in relation to the unsupplemented group, irrespective of the level of the added enzyme. In maize-rapeseed diets practically no significant influence of the applied enzyme on FCR was observed, although utilization was slightly better in group 8 with the higher level of enzyme.

In all groups phytase supplementation caused an increase of feed intake (Table 3). In group fed rapeseed meal supplemented with 750 units of phytase per $\mathrm{kg}$, feed intake was $3 \%$ higher in relation to the respective control group. The higher feed intake, at a very similar FCR (Table 3), resulted in better body weight gains in groups 7 and 8.

.The results of slaughter analysis are shown in Table 4. The lowest dressing percentage was observed in chickens fed diets with the lower Pt content and without phytase supplementation. Addition of phytase improved dressing percentage, especially in groups fed maize-rapeseed diets. No significant 
TABLE 4

Slaughter analysis, $\%$ of live body weight

\begin{tabular}{lcrrrrrrrr}
\hline & \multicolumn{7}{c}{ Group no } & SEM \\
\cline { 2 - 7 } Item & 1 & 2 & 3 & 4 & 5 & 6 & 7 & 8 & \\
\hline $\begin{array}{l}\text { Dressing } \\
\text { percentage }\end{array}$ & $65.8^{\mathrm{a}}$ & $65.5^{\mathrm{a}}$ & $66.4^{\mathrm{ab}}$ & $66.9^{\mathrm{ab}}$ & $66.5^{\mathrm{ab}}$ & $64.3^{\mathrm{a}}$ & $70.4^{\mathrm{c}}$ & $69.1^{\mathrm{bc}}$ & 1.011 \\
$\begin{array}{l}\text { Skin with } \\
\begin{array}{l}\text { subcutaneous } \\
\text { fat }\end{array}\end{array}$ & 8.2 & 7.8 & 8.1 & 8.2 & 7.4 & 7.1 & 7.2 & 7.6 & 0.509 \\
$\begin{array}{l}\text { Leg muscles } \\
\begin{array}{l}\text { Breast } \\
\text { muscles }\end{array}\end{array}$ & 19.9 & 21.6 & 19.9 & 20.5 & 21.6 & 20.5 & 19.9 & 20.0 & 0.725 \\
\hline
\end{tabular}

$\mathrm{a}, \mathrm{b}-\mathrm{as}$ in Table 3

differences among groups were found in percentage share of skin with subcutaneous fat and muscles.

The health of chickens in the growth experiment was satisfactory, deaths were rare, random and not connected with the experimental factor.

TABLE 5

$\mathrm{P}$ and $\mathrm{Ca}$ utilization, $\%$

\begin{tabular}{lccccccccc}
\hline \multirow{2}{*}{$\begin{array}{l}\text { Week } \\
\text { of life }\end{array}$} & 1 & 2 & 3 & 4 & 5 & 6 & 7 & 8 & \multirow{2}{*}{ SEM } \\
\cline { 2 - 8 } & \multicolumn{1}{c}{ Group no } \\
\hline Phosphorus & $48.7^{\text {bc }}$ & $41.5^{\text {ab }}$ & $42.4^{\text {abc }}$ & $51.4^{\mathrm{c}}$ & $51.0^{\text {bc }}$ & $35.7^{\mathrm{a}}$ & $41.2^{\text {ab }}$ & $46.0^{\text {bc }}$ & 3.511 \\
Calcium & $40.9^{\text {cd }}$ & $41.5^{\text {cd }}$ & $32.1^{\text {ab }}$ & $34.5^{\text {ab }}$ & $40.5^{\text {bcd }}$ & $29.1^{\text {a }}$ & $29.5^{\text {a }}$ & $43.3^{\text {d }}$ & 2.667 \\
\hline
\end{tabular}

a, $\mathbf{b}$ - as in Table 3

The results of a balance experiment are presented in Table 5. The lowest $P$ utilization was observed in groups fed low-phosphorus unsupplemented diets (2 and 6). Administration of the enzyme, especially in its higher dose of 750 units per $\mathrm{kg}$, increased phosphorus availability by $24 \%$ in the case of soyabean meal-based diets and by $29 \%$ in the case of rapeseed meal-based diets. The obtained results were similar to those reported by Dänicke et al. (1995) and Rutkowski and Potkański (1995). In contrast to the study by Simons and Versteegh (1993), but similarly to studies by Potkański et al. (1995), addition of phytase was not always found to increase calcium digestibility. 


\section{CONCLUSIONS}

Addition of 750 units of phytase per $\mathrm{kg}$ to diets with a lowered phosphorus content increased Pt utilization by $24 \%$ in diets with soyabean meal and by $29 \%$ in diets with rapeseed meal. The studied phytase preparation seems to be particularly suitable for diets containing high levels of rapeseed meal.

For a significant improvement of performance of chickens fed maizesoyabean diets, 250 units of phytase per kg may be adequate, while in the case of maize-rapeseed meal diets, 750 or more units of phytase per $\mathrm{kg}$ are required.

\section{REFERENCES}

Barylko-Pikielna N., 1975. An Outline of Food Sensory Analysis (in Polish). PWN, Warszawa

Dänicke S., Kracht W., Jeroch H, Potkański A., Rutkowski A., 1995. Effect of graded phytase supplementation to semi-synthetic diets based on rapeseed meal or rapeseed meal expeller fed to broilers and laying hens. 10th European Symposium on Poultry Nutrition, Antalya (Turkey), pp. 364-365

Jeroch H., 1994. Bis jerige Erkenntnisse zum Phytaseeinsatz beim Geflügel. Archiv Geflügelk. 58, 1-7

Kratzer F.H., Vohra P., 1986. Role of phytic acid and other phosphates as chelating agents. Biochem. Biophys. Acta 302, 316-328

Nelson T.S., Shieh T.R., Wodzinski R.J., Ware J.H., 1971. Effect of supplemental phytase on the utilization of phytate phosphorus by chicks. J. Nutr. 101, 1289-1293

Nutrient Requierement of Poultry (in Polish), 1996. The Kielanowski Institute of Animal Physiology and Nutrition, 3rd Edition, Jabłonna, Poland

Nwokolo E.N., Bragg D.B., 1980. Biological availability of minerals in rapeseed meal. Poultry Sci. $69,155-158$

Matyka S., Ward G.A., Bogusz G., Korol W., 1991. Retention of different forms of phosphorus from DKA type diets in broiler chickens (in Polish). Biul. inf. Przem. Pasz. 30, 1, 63-70

Olsen S.R., Sommers L.E., 1982. In: A.L. Page, R.H. Miller D.R. Keeney (Editors). Methods of soil analysis. Part 2. Chemical and microbiological properties. Madison, Wisconsin, USA, pp. 403-430

Potkański A., Dänicke S., Rutkowski A., Jeroch H., Kracht W., 1995. Availabity of phosphorus of rapeseed meal and rapeseed meal expeller for growing chickens and improvement of phosphorus availability by graded enzyme addition. Proceedings of 9 th International Rapeseed Congress, Cambridge, Vol.1, pp. 157-160

Rutkowski A., Potkański A., 1995. Improvement of utilization of phytic phosphorus from rapeseed meal by application of phytase in experiments on chickens (in Polish). IHAR, Rośliny Oleiste $16,369-374$

Simons P.C.M., Versteegh H.A.J., 1993. Role of phytases in poultry nutrition. Proceedings of 1st Symposium on Enzymes in Animal Nutrition, Kartause Ittingen, pp. 181-186

Żyła K., Koreleski J., 1993. In vitro and in vivo dephosphorylation of rapeseed meal by means of phytase-degrading enzymes derived from Aspergillus niger. J. Sci. Food Agric. 61, 1-6 


\section{STRESZCZENIE}

\section{Zastosowanie fitazy w dawkach zawierających kukurydzę i śrutę sojową lub rzepakową dla kurcząt brojlerów}

Przeprowadzono dwa doświadczenia, których celem było określenie możliwości ograniczenia stosowania fosforanów paszowych w mieszankach kukurydziano-sojowych i kukurydziano-rzepakowych dla brojlerów przez zastosowanie enzymu fitazy. W doświadczeniu 1, przeprowadzonym na 560 kurczętach brojlerach (równa liczba kurek i kogutków), badano wpływ dodatku fitazy na przyrosty masy ciała, spożycie paszy oraz liczbę upadków. Po zakończeniu doświadczenia ubito po 3 kurki i 3 kogutki z każdej grupy i wykonano analizę rzeźną. Dodatek fitazy spowodował zwiększenie spożycia paszy, przy bardzo zbliżonych współczynnikach wykorzystania paszy, co było powodem lepszych przyrostów masy ciala kurcząt $w$ grupach $z$ dodatkiem enzymu. Dodatek fitazy spowodował także poprawę wydajności rzeźnej, szczególnie w grupach żywionych dietami kukurydziano-rzepakowymi. W doświadczeniu 2 - bilansowym, przeprowadzonym na 80 kurczętach, określono dostępność Ca i P. Dodatek fitazy spowodował wzrost dostępności fosforu, w przypadku mieszanki sojowej o $24 \%$, a mieszanki ze śrutą rzepakową o $29 \%$.

Zastosowanie fitazy pozwala na stosowanie w odchowie kurcząt rzeźnych mieszanek paszowych o obniżonym o $33 \%$ poziomie fosforu dostępnego. 